Témoigner Témoigner. Entre histoire et mémoire

Getuigen Revue pluridisciplinaire de la Fondation Auschwitz

$123 \mid 2016$

Traduire le témoignage

\title{
Interview with Holocaust Historian Gideon Greif
}

\section{Frédéric Crahay}

\section{(2) OpenEdition}

\section{Journals}

\section{Electronic version}

URL: https://journals.openedition.org/temoigner/5128

DOI: 10.4000/temoigner.5128

ISSN: 2506-6390

\section{Publisher:}

Éditions du Centre d'études et de documentation Mémoire d'Auschwitz, Éditions Kimé

\section{Printed version}

Date of publication: 1 October 2016

Number of pages: $54-57$

ISBN: 987 2-9600926-4-6

ISSN: 2031-4183

\section{Electronic reference}

Frédéric Crahay, "Interview with Holocaust Historian Gideon Greif", Témoigner. Entre histoire et mémoire [Online], 123 | 2016, Online since 02 November 2021, connection on 04 November 2021. URL: http:// journals.openedition.org/temoigner/5128; DOI: https://doi.org/10.4000/temoigner.5128 
Professor Gideon Greif is well-known for his pioneering research on the

Sonderkommandos, prisoners who were forced to work in the gas chambers and crematoria of the Auschwitz-Birkenau concentration and extermination camp. Some of them moved to Israel afterwards. In 1986, when he realized that the matter had received very little attention until then, Greif began collecting interviews of these tormented men and managed to gather a unique collection of testimonies that conveys the voices of these unlikely survivors. Indeed, as "bearers of secrets" (Geheimnisträger) from the Nazi perpetrators, the men were not supposed to live and share their story. Last year, Gideon Greif and Itamar Levin published Aufstand in Auschwitz (2015), a study about the revolt of the Sonderkommandos in Birkenau on 7 October 1944 - an unexplored event. It was one of the numerous acts of resistance against the Nazis that the Jewish people undertook in occupied Europe.

$\rightarrow$ By Frédéric Crahay

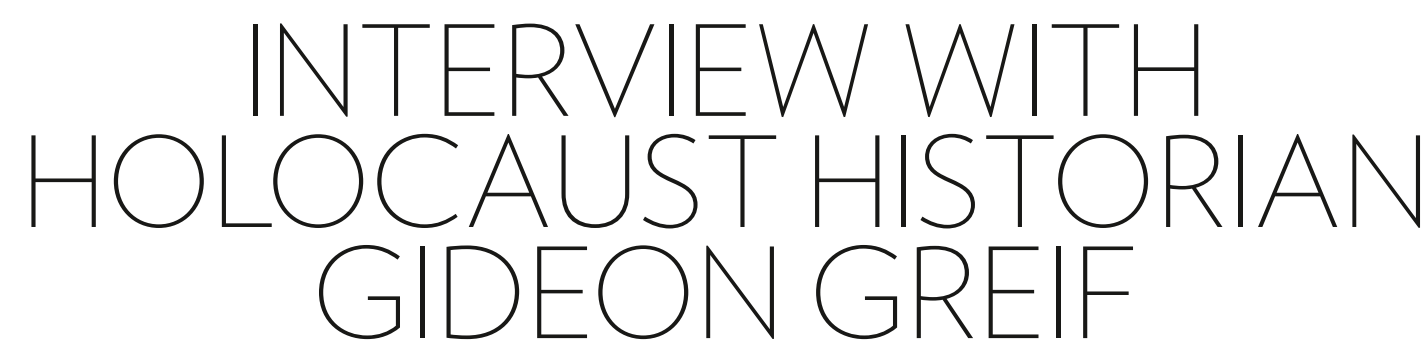

Gideon Greif, you decided a long time ago to dediate your scientific career to the history of the Holocaust. Was your family personally involved in the genocide of War?

Professor Gideon Greif: Yes, my family was involved in the horrors of the Holocaust. My grandfather, Dr Karl Danziger, was a Jewish physician in Hindenburg (Upper Silesia). He was arrested on 9 November 1938 the beginning of Kristallnacht, and deported to Buchfor more than five months. He suffered tre prisoner for cally during his imprison cally during his imprisonment in Buchenwald that my aunt, llse-Lore, could notidentify her own father when release from the camp.
A few days later, my grandfather left Germany with is family: my grandmother, Dr Elfriede Danziger, my mother Betrice, and my aut nother Beatrice, and ny aunt Ilse-Lore. I have to the horsize that ny grandfather never recovered from The

The sister of my grandmother, Gertrude (Trude) Goldmann, could have left Germany in time and saved her found refuge in Shanghi, the of my grandmothe that did not demand a visa for entering the world here until the end of the war.

You obtained your PhD at the University of Vienn in Austria. How do you remember those years of study, the horrors he underwent in Buchenwald. He carried until she passed away. It was then too late to leave Germany, Gertrude was deported to Auschwitz in 1943 and

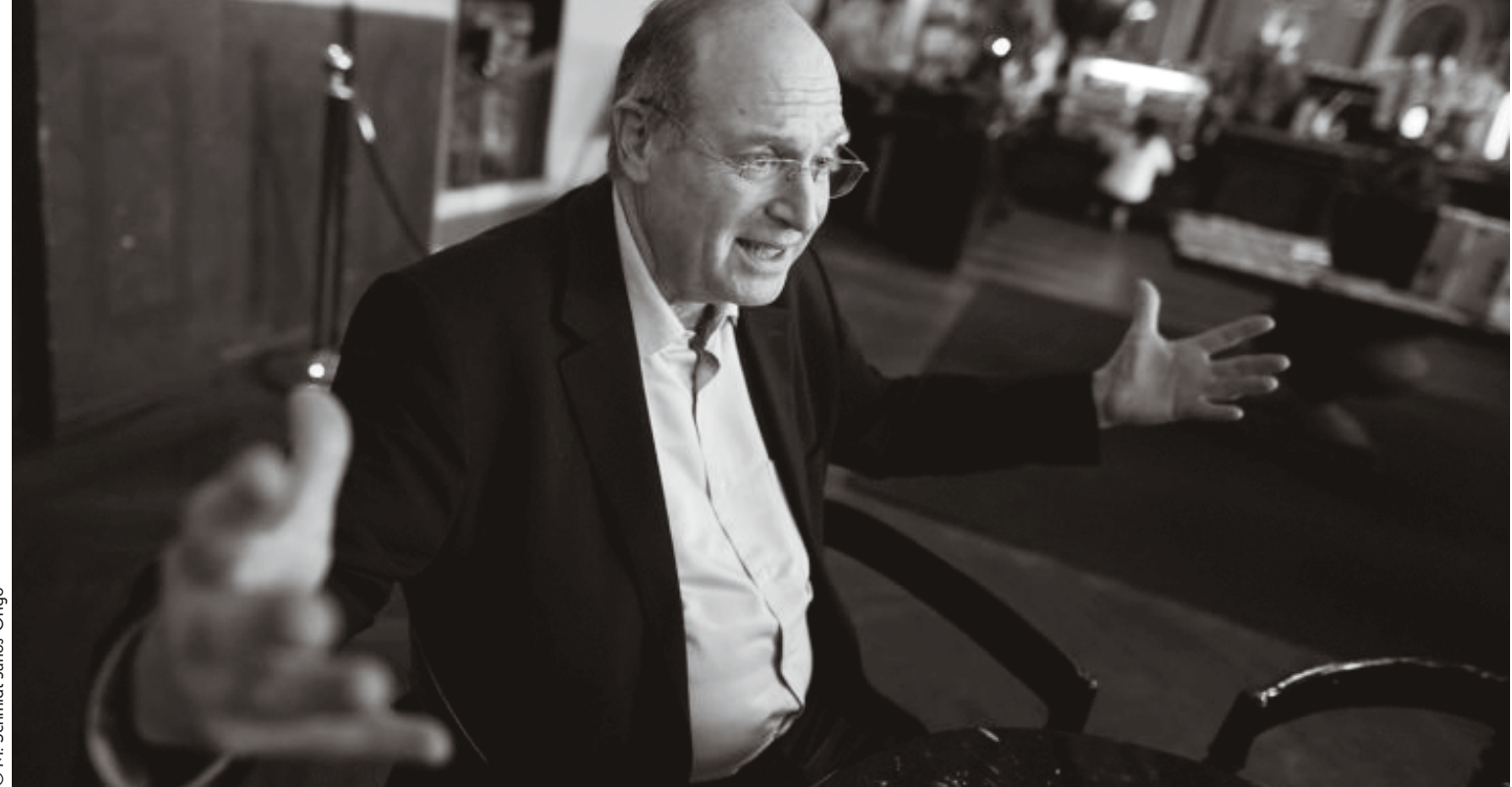

and what did they mean for your career as a Holocaust historian?

The decision to obtain my PhD was in a way spontaneous, not the result of any particular intention of Yad Vashem, we becar friends and he Yad Vashem, we becane frier Ge my Doktorvater at the University of Vienna where he was teaching. Studying in Vienna was a special experence for in Vience my was in a Besides, I net very nice scholars there and was surrounde by real fiends with whom I anstill in touch today. The years I spent as a student in Vienna were aieng the happiest of my life. Always when I am in Vienna, mosty for lections. Also, Vient

Also, Vienna was a very important Jewish spiritua centre dignifed and old university.

Since 2013, you have been Chief Historian at the Shem Olam Institute for Education. Documentation Shem Olam Institute for Education, Documentation and Rese is this position to you? valuable is this position to you?
The work at Shem Olam opened up new dimensions uments the individual aspects of Jewish resistance during the Holocaust - a resistance that manifested itself in arious ways: religious, spiritual, moral and others. Fo many years, Jewish historiography on the Holocaust emphasized armed resistance, uprisings with weapon in hand, as a symbol for Jewish active resistance again he Germans and their collaborators. Shem Olam state that the masses of Jews, who did not have the privilege of being armed and who had no military experience, fought bravely for their life as well. Mothers, father and children were fighting their own battles for one extra hour of survival, for one extra day of living. This hould be resistance is just as heroic as any other and

I am pry proud to be Chif

$I$ am very proud to be Chiee Historian of this institute, which is considered one of the most excellen colocaust is consilals in Israel where thousands of new aspects of the Holocaust.

You conducted very important research based on interviews with former Sonderkommando members. Th lished in the book We Wept without Tears How did the world feel about the Sonderkom- 000 for myscientific work. The institute researches and doc- 
$\ldots$ mando members back then, and today? Has our attitude owards them changed? Primo Levi, in The Drowned and the Saved,considers them akin to collaborators. That

My goal, by initiating the Sonderkommando project 1986 , was primarily to document the testimonies of che tories The Sonderkm ando surviver are the only tories. The Sonderkommando survivors are the only on we industrial murder in Auschwitz, from the beginning interview all thirty living survivors of the Sonderkminterviow all thrty living survors or the mando all over the world. This resulted in a precious to be interviewed, although he correspovis to be interviewed, although he correspondit withe

My second gol, which was equally succesful, was My second goal, which was equally successful, was to counter the negative image or the Sondenommando prisoners. In numerous testimonies by Auschwitz survivor, Jews and rimbers were described in very dark colours, somethe they were even accused of being murderers. From the very begining, I felt that these accusations were just: the mators. In fact, they were the most miseraot perpetrats. cir their reputation by telling the truth about them. In my pewer to save the honour and humanity of the Jews power to save the honour and humanity of the Jews with dignity and mercy and to make their final minutes with dignity and mercy and to makn I would minutes somewhat bearable. As an example I would mention what Joser Sackar, a Greek survivor, told me: wheneve Jew the looked the of she

I am proud to say that, thanks to this kind of research, public opinion on the Sonderkommando ha significantly changed. Nobody would call them traitors, collaborators or murderers anymore. Even Primo ench situation at the time.

Last year, director László Nemes released his film Son of Saul. It tells the story of a fictional member of the Sonderkommando at Birkenau, Saul Ausländer, who wants to salvage the body of a boy he takes for his son and bury it properly. What are your thoughts on the film?

I met László Nemes in Tel Aviv for intensive talks wo years ago, before he started to shoot Son of Saul. He promised me to make every effort not to repeat the mando mando, The Grey Zone (2001). When I watched Nemes production, I was relieved. He had kept his promise and protected the dignity of the Sonderkommando prisonwhen I saw it. I

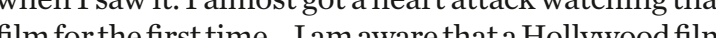
do mor the film does not have to be a hundred per cent accurate - afte dignity of a documentary - but it should honour the gando deserve to be treated better than they were The Grey Zone. The Grey Zone.

Nemes on the other hand is a great director. He is ensitive, understands the historical background, and his actors were well prepared for their sensitive roles. So yes, I like Son of Saul and I am very glad the film to wo so many prestigious prizes. Praise to mando, finally!

In the film we see the uprising of the Sonderkommando of Krematorium $/ V$ on 7 October 1944 in Birkenau. László Nemes read your study We Wept without Tears before making Son of Saul. I take it you appreciate the result?

Yes, Nemes did a brilliant job. I am very pleased that my book inspired him to make such an excellent hat my book inspired him to make such an excellen film. Nemes is one of those directors who spend much ine on research for their script before they start shootg. When we met in Israel, he asked me hundreds of questions relating to the smallest details. His curiosity was absolutely impressive. This was not the case with the producers of The Grey Zone: they ignored my critcism, which I connunicated to them before the film was completed, and the result is therefore horrible. tószlow Nemes is young, but extremely gifted and open to new ideas. During our meeting, I immediately got the impression that he understood the gravity of the in the flestedseveralideas with in the film, and I am very grateful for his sensitivity. Telicate and the most compando squads is the most the Holocaust.

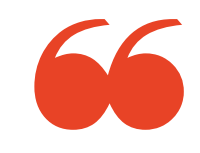

The subject of the

Sonderkommando squads is

the most delicate and the mos

complex in the entire history of

the Holocaust

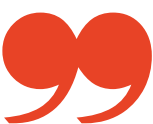

As a leading researcher in Holocaust studies, which fields remain underexposed in your view?

A very important, yet largely unexplored field is the Aver world and soul of the German murderers. We still do not have a thorough picture of the motives of the men and women who conducted the crime against the Jewish people - who humiliated, tortured and murdered millions of Jews. I am thinking of an interdisciplinary study, since you would have to investigate the psychlogich and a study, which 1 believe should be launched by Ger. hunan in the future.

Thation, we lack monographies on importan ghettos, and also on many concentration camps. One particular interinion camp, Majdanek, has been ne one beone of my next projects. Majdanek through the eyes of interviews of Majdanek survivors.

In international politics today, there is debate about the need to "deradicalize" certain youngsters involved with radical Islam. The Holocaust can prove to be a very sensive and difficult subject to address at school in this context. But lunderstand hat you gave Holocaust lectures in Germany for an exclusive Muslim audience, as a way of moving beyond these stereotypes. Can you tell us a littl
My experience with Muslim students and teachers was indeed promising: they listened carefully, aske any questions. the seened to me that the the muthe Hews. I would like to conpathic with the murder Jews. I would like to continue my lectures before a Mush ariects thout the Holocaust I have developed a specific about he Holocaust. Ihave developed a specific didactic mo cor most important challenges in my field.

You have just finished a study on the Sonderkommando uprising. Besides Majdanek, which new projects will you be working on in the future?

I am indeed writing a book on the Majdanek extermination camp, but also one on the Greek Jews in mination camp, but also one on the Greek Jews in from Slovalia to Auschwitz Mymostimportart from Slovakia toAuschwitz. Mymost important project, mando, is a mprehiting with my Gor conder whe but they are a little premature; I feel it is too early to publish at a pur hol this meeds thousands of more yeying that eing fully researched.

Works cited

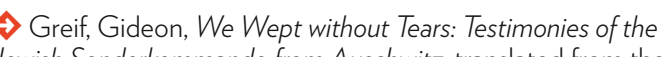
Jewish Sonderkommando from Auschwitz, translated from the

University Press, 2005

$\Delta$ Greif, Gideon \& Itamar Levin, Aufstand in Auschwitz: die "Sonderkommandos" am 7. Oktober 1944 Vienna: Böhlau, 2015

$\Delta$ Levi, Primo, The Drowned and the Saved, translated from the
Italian by Raymond Rosenthal, New York: Summit Books, 1988. $\diamond$ Son of Saul, director László Nemes, Laokoon Film Group,

$\triangle$ The Grey Zone, director Tim Blake Nelson, Lionsga

Learn more

$\diamond$ Greif and Levin's book Aufstand in Auschwitz is currently

being translated in French and Dutch by the Auschwitz 